\title{
THE THIRD BOSPHORUS BRIDGE AND THE NORTHERN MARMARA MOTORWAY PROJECT
}

\author{
F. BÜYÜKYORAN ${ }^{1} \&$ S. GÜNDEŞ ${ }^{2}$ \\ ${ }^{1}$ Department of Architecture, Mimar Sinan Fine Arts University, Turkey \\ ${ }^{2}$ Department of Architecture, Mimar Sinan Fine Arts University, Turkey
}

\begin{abstract}
Build-operate-transfer (BOT) model is extensively used by many governments throughout the world for the realization of large-scale transportation projects. As a rapidly developing economy, Turkey is also increasingly referring to the use of the project finance model for delivering large-scale transport, energy and healthcare projects. Istanbul, located between Asia and Europe, is one of the most important economic centres of the country. Based on this model, rapid urbanization and population growth are taking place in the city. Growing concerns over the insufficiency of the existing two bridges in meeting the traffic demands of cross-continental transport in Istanbul have urged central and local governments to find a solution for the traffic congestion problem. As a result, the government of Turkey has announced plans for building a new bridge to connect the European and Asian sides in early 2011. The construction of the new Bosphorus Strait Crossing Project which has started in 2012 is expected to be completed by 2015. However, since its launch, the project faced many diverse challenges such as delayed tendering, legal disputes, financial problems and social opposition. This study aims at exploring the problems experienced and the solutions developed as a response to these problems in the implementation and management of the third Bosphorus Bridge and the Northern Marmara Motorway Project using a case study approach. To achieve this objective, necessary data regarding the tendering process were collected from various sources. The conclusion provided at the end of this case study is expected to enhance our understanding of the use of BOT model for transport projects and risk allocation between different actors. Both public and private sector participants that are involved in delivering transport projects using the BOT model may benefit from the findings of this study.
\end{abstract}

Keywords: built-operate-transfer, case study, guarantees, risks, toll roads, transportation projects, Turkey

\section{INTRODUCTION}

Istanbul is the most populated and economically important city in Turkey, which is located between two continents, Europe and Asia. The city is known by its notable Bosphorus Strait which connects the Black Sea in the north to the southern seas (Marmara, Aegean and finally the Mediterranean) and also Asia to Europe. Thus, the Bosphorus Strait is considered to be world's one of the most important sea and land transport centres.

The oldest idea in building a connection between two continents dates back to the Persian King Darius, who crossed his army from the Strait by a bridge made of boats. Since then, a variety of different ideas were put forward, especially in the last century of the Ottoman Empire (1800s) such as the Hamidian Bridge and several Tunnel projects. However, only in 1973, the first connection between the two continents could be established by the completion of the first Bosphorus Bridge. Later in 1988, the second bridge was constructed in approximately $5 \mathrm{~km}$ north of the first bridge. Upon realization of the insufficiency of these two bridges in overcoming the traffic congestion problem, the Marmaray Rail Tube Tunnel Project was also launched (see Gundes and Ergonul [1]) and entered into service in 2013. In addition, the construction work is going on to complete the Avrasya highway tube tunnel which has started to be realized with the build-operate-transfer (BOT) model in 2011. 
The accelerated population growth in the city, which by now amounts to approximately 14 million, consequently caused the physical boundaries to grow outwards. The salient growth in particular towards north and the continuing traffic congestion problem in the two bridges fostered interest in the construction of a third bridge in the northernmost point of the Bosphorus Strait. In 1997, 9 years after the completion of the second bridge, the Ministry of Construction has announced its plans to build a new bridge on Bosphorus Strait. However, studies were accelerated only after 2004 when the current government announced that they were reconsidering its construction. Finally, in 2011, the third bridge and connection highways project was opened to tender using the BOT model. However, a variety of problems became evident from the beginning. Preliminary concerns raised about the project were the controversial location of the bridge and the route of the connection highways as the selected region is characterized by forests recognized as the 'lungs of the city' and watersheds. Concerns surrounding the project were not only limited to environmental issues. As the project started to evolve, several other problems regarding the organizational, financial and risk allocation structure emerged. All these challenges necessitated major alterations to the scope and structuring of the BOT project.

This study explores the organizational, financial, economic, social and environmental challenges experienced in the realization of the third Bosphorus Bridge and the Northern Marmara Motorway Project using a case study approach. According to Proverbs and Gameson [2], the case study research is highly relevant to those industries that are project based and have many different types of organizations. As the use of case studies as a research method provides 'a source of insights and ideas in the early stages of investigating a topic' (Fellows and Liu [3]), and thus expands existing knowledge, it is highly important for future research. The necessary data regarding the tendering process were collected from articles, archives, interviews and briefings of associated institutions in both public and private sector. In this concept, emphasis was given to the use of BOT model and the allocation of risks between private and public sectors. The next section provides a brief overview of the location and technical structuring of the project.

\subsection{Background of the project}

Today, Istanbul's population has reached 14 million and there are approximately 3 million vehicles. Considering the transit pass through the city, it is estimated that everyday approximately 15 million people travel on roads and highways. Despite efforts to expand railway and sea transport in the city, roads and highways still carry $87 \%$ of traffic load. Consequently, while the daily capacity of the existing bridges is 250,000 , approximately 600,000 vehicles cross the bridges connecting the two continents. Therefore, the first aim of the project was to tackle the traffic congestion problem and to establish the more secure highway infrastructure in the Marmara region. Accordingly, the project further aims to minimize the economic loss resulting from long travel times in the city and the corresponding high levels of fuel consumption, to reduce emissions and noise, and to enable an interrupted transit freight between the two continents.

After many alterations to the project scope which will further be examined, the final project included the construction of a highway passing through the northern part of Istanbul and of a bridge connecting the two continents between Garipce and Poyrazkoy. In this concept, $60 \mathrm{~km}$ of highway ( $2 \times 4$ lanes), $35 \mathrm{~km}$ of connecting roads $(2 \times 4$ lanes $)$ and a 2,164 $\mathrm{m}$ long bridge $(2 \times 4$ motorway and $2 \times 1$ railway) will be built. 




Figure 1: Turkey Planned Highway Network until 2030 (source: KGM [4]).

As shown in Figure 1, the route of the project is designed to be connected to several existing and ongoing motorway and bridge investments. These include connections to the existing Trans-European Motorway and to the ongoing BOT Gebze Izmir Motorway Project involving the Izmit Bay Bridge. Furthermore, the project will also provide a connection to the Tekirdag, Canakkale and Balikesir Motorways. All these investments enable Istanbul to connect to the southern regions of the country.

A high interconnectedness is also planned for the railway system on the bridge and the existing infrastructure investments in the city. In this concept, connections to Marmaray and the current subway lines are expected to link the old Atatürk airport in the European side, Sabiha Gokcen airport in the Asian side and the ongoing third airport. However, perhaps the most important project that the third Bosphorus Bridge and the Northern Marmara Motorway interacts is the ongoing third airport for Istanbul. The BOT airport project will be the largest airport in the world when completed in 2017. Figure 1 shows the location of the new mega airport project and its connection to the Northern Marmara Motorway.

The first tender was opened in 2011. However, no bids were submitted in the first tender as the perceived risks of private investors were very high. The failure in the first tender was a turning point for the scope and risk allocation structure of the project. Therefore, the challenges and the ways of which these problems are dealt with are discussed in detail in the next section. The date of the second tender was 20 April 2012 (Anadolu Ajans1 [5]). Tables 1 and 2 show the names and country origins of companies that have purchased tender documents for the first and second bidding of the project. As shown in Tables 1 and 2, while 18 firms including nine foreign firms purchased documents in the first tender, only three foreign and eight Turkish firms have expressed interest in the second tender. Therefore, it can be stated that the interest of foreign firms for the project has significantly decreased after the project scope was narrowed. 
Table 1: Companies that have purchased tender documents for the first bidding.

\begin{tabular}{lll}
\hline No & Company & Origin \\
\hline 1 & Stradag & Germany \\
2 & FCC Construction & Spain \\
3 & Astaldi & Italy \\
4 & Obayashi & Japan \\
5 & Mitsubishi & Japan \\
6 & Itochu & Japan \\
7 & IHI & Japan \\
8 & Moskovskiy Metrostroy & Russia \\
9 & OOO NPO Mostovik & Russia \\
10 & Mapa Construction & Turkey \\
11 & Cengiz Construction & Turkey \\
12 & Park Holding & Turkey \\
13 & Varyap & Turkey \\
14 & Yuksel Construction & Turkey \\
15 & Kolin Construction & Turkey \\
16 & Nurol Construction & Turkey \\
17 & STFA & Turkey \\
18 & Gulsan Construction & Turkey \\
\hline
\end{tabular}

Table 2: Companies that have purchased tender documents for the second bidding.

\begin{tabular}{lll}
\hline No & Company & Origin \\
\hline 1 & Astaldi & Italy \\
2 & Salini & Italy \\
3 & POSCO E\&C & S. Korea \\
4 & Mapa Construction & Turkey \\
5 & Cengiz Construction & Turkey \\
6 & Park Holding & Turkey \\
7 & STFA & Turkey \\
8 & Guris Construction & Turkey \\
9 & Atli Machine Const. & Turkey \\
10 & Yapi Merkezi & Turkey \\
11 & Alsim Alarko & Turkey \\
\hline
\end{tabular}


Table 3: Companies that have submitted bids in the second tender.

\begin{tabular}{llll}
\hline No & Company & Origin & Status \\
\hline 1 & Salini-Gulermak JV & Italy-Turkey & Accepted \\
2 & Ictas-Astaldi JV & Italy-Turkey & Accepted \\
3 & China Communications Construction- & China-Turkey & $\begin{array}{l}\text { Rejected (missing } \\
\text { document) }\end{array}$ \\
& Dogus-Yapi Merkezi-Arkon JV & Rejected (technical \\
4 & MAPA Construction & Turkey & incompetence) \\
& Cengiz-Kolin-Limak-Makyol- & Turkey & Accepted \\
\hline
\end{tabular}

Table 3 shows the names of the five joint ventures and companies that have submitted bids in the second tender. The application of the joint venture led by China Communications Construction (no. 3) was rejected from the start due to missing documents in the bidding file. The technical competence of bidders was then evaluated using a point scoring system out of a maximum of 100 points. Three joint ventures, namely Salini-Gulermak, Ictas-Astaldi and Cengiz-Kolin-Limak-Makyol-Kalyon, were able to pass the required 70 points in the evaluation of technical competence.

Finally, evaluations were completed and the successful bidder was announced on 29 May 2012. Ictas Insaat Sanayi Ticaret AS-Astaldi JV (ICA) won the tender with a concession period of 10 years, 2 months and 20 days. The construction would be completed in 36 months with a cost of approximately 2.9 billion US dollars. Therefore, the duration of the operation by the JV is approximately 7 years. The second bidder Cengiz-Kolin-Limak-Makyol-Kalyon JV proposed a concession duration of 14 years, 9 months and 19 days which is approximately $40 \%$ longer than the winning bid (Anadolu Ajans1 [6]).

The due date for the commencement of construction works was fixed in the contract specifications; therefore, the ministry announced that the winning bidder was obliged to start construction works with equity even if the required funds could not be obtained on time from financial institutions (CNN Türk [7]). The construction of works has started in 2012 after the second tender and will be completed in 2015. The concessionaire will operate the bridge and highways for approximately 7 years, and the infrastructure will then be transferred to Turkish government at the end of the concession period.

\subsection{Organizational structure}

The project company, ICA joint venture, comprises two groups of shareholders including Turkey-based IC Ictas which holds $66.6 \%$ of shares, and Italy-based Astaldi which holds the remaining $33.3 \%$. These two groups also have previously formed a joint venture for the realization of the West High Speed Diameter Project in Russia and the new airport of St. Petersburg.

The French structural engineer Dr. Michel Virlogeux and the Swiss T-Engineering have jointly assumed the conceptual design of the project. Belgian Greisch (structural calculations and construction methods), Temelsu International Engineering Services Inc. (Turkey), Swiss 
Lombardi Ltd. (evaluating the thermal behaviour of the bridge's tower shafts and approach slabs due to concrete pouring), French CSTB (aerodynamic performance), Dutch Fugro (foundation design) and SETEC (design control) have also contributed to the design of the bridge.

The construction contract for the bridge was awarded to the joint venture comprising South Korea-based Hyundai E\&C and SK E\&C with shares of $60 \%$ and $40 \%$, respectively. The contract that was signed on July 2013 valued 697 million dollars (Construction Week [8]).

\subsection{Financial structure}

Total project cost is approximately 2.9 billion US dollars. Debt to equity ratio is 80/20. Six local banks, namely Garanti Bankasi, AS (366 million US dollars), Halk Bankasi AS, İs Bankasi AS, Vakiflar Bankasi TAO, Ziraat Bankasi AS and Yapi ve Kredi Bankası AS (386 million US dollars each), and one Netherlands based bank Garantibank International NV (20 million US dollars) agreed to underwrite the 2.3 billion loan. The loans provided by banks have a maturity of 9 years and 5 months. Therefore, the repayment is planned to be completed on 5 March 2023.

The remaining 600 million US dollars is provided as equity by the two shareholders in the project company. According to contract specifications, the project company is obliged to start construction works in 6 months after signing of the contract. However, ICA JV has started construction in September 2012, before the due date, using 581 million US dollars of equity. In accordance with the respective shares of $66.6 \%$ and $33.3 \%$ of the two companies in the joint venture, 387.33 million US dollars of the equity is provided by IC Ictas and the remaining 193.67 million US dollars is provided by Astaldi.

A notable feature of financial agreements was the small amount of foreign funding despite the wide range of government guarantees and special rights provided to the project. Indeed, the use of local capital markets in financing private toll road projects is a preferred option for many projects worldwide. Fishbein and Barbar [9] provide several reasons for the recourse to local finance in toll road projects. First, foreign exchange risks can be mitigated by the use of local capital as the currency of toll revenues generated by the project and the debt service will be the same. Second, financial negotiations will be easier as local financial institutions with a better understanding of the local context are more willing to assume economic and political risks. Third, raw materials and other inputs required in the construction of toll road projects can generally be provided locally. Therefore, there is no need to fund construction costs in a foreign currency.

Although the majority of banks in the third bridge and Northern Marmara Motorway Project were local, the loans were obtained in foreign currency. Foreign exchange risks were mitigated through toll payments based in the same currency [e.g. bridge: 3 US dollars + VAT (cars), 15 US dollars + VAT (heavy vehicles); highways: 0.08 dollars $/ \mathrm{km}]$. Therefore, limited ability to attract foreign capital cannot be attributed to foreign exchange risks but to other problems and risks surrounding the project. These are examined in the next section with explanations about the way in which and how the problems are dealt with in our BOT toll road representative case. In this concept, key lessons learned regarding the application of the BOT model for transportation infrastructure are also emphasized.

\section{CHALLENGES ENCOUNTERED AND PROPOSED SOLUTIONS}

In addition to the social and environmental concerns surrounding the project, the tendering process of the new bridge also received heavy criticism from opponents. The first bidding process for the BOT project had to be cancelled as no bids were submitted due to financing 
problems. Thus, the project could only be put to tender again after some important modifications were made to the project and to existing specifications including government guarantees, the scope and several legal arrangements. The remaining part of this section addresses the challenges encountered in the tendering process by examining the differences between two tenders in detail. In this concept, risk allocation between parties and guarantees provided by the public sector will be emphasized in order to clarify how the aforementioned modifications could enable the feasibility of the project for investors.

\subsection{Project scope}

As a response to the failure in the first tender, the government displayed determination to realize the project by stating that other procurement models such as the traditional and international agreements could also be considered in case there will be no demand for the BOT model. Indeed, this statement showed the commitment of the government and the importance attached to the realization of the third bridge project.

First considerations regarded reductions in the scale. The project in the initial tender contained several different major parts that could be considered as subprojects such as highways, a bridge and connection roads. Accordingly, the capital investment in the first tender amounted to approximately 6 billion US dollars. Thus, it is not unexceptional that problems in the provision of finance are encountered as the resulting financial costs were very high. Press statements after the failure in the first tender signalled revisions in the scope and specifications of the project. The first move was to divide the project into two separate subprojects that will be tendered separately in order to reduce the total cost. As stated earlier, $299 \mathrm{~km}$ of highways, $115 \mathrm{~km}$ of connection roads and the bridge were altogether put to first tender. However, in the second tender, the Ministry announced that the bridge, $60 \mathrm{~km}$ of highways and $35 \mathrm{~km}$ of connection roads would again be realized by the BOT model. The remaining highways and connection roads, on the other hand, would be realized through traditional procurement system. In this way, the project cost was reduced from an estimated 6 to 2.9 billion. US dollars (Habertürk [10]). Moreover, this new reduction in the scope would also reduce the construction time from an estimated 5 years and 10 months to 3 years.

\subsection{Market demand (revenue) risks}

A major difference between the two tenders concerns revenue risks assumed by investors. The investors attributed the lack of bids in the first tender to the difficulty in obtaining finance for the project due to the insufficiency of government guarantees provided (e.g. see Hürriyet [11], Reuters [12]). Minimum traffic volume guarantees provided by the public sector were perceived to be insufficient and the allocation of risks between the public and the private sector was problematic.

Early statements by the General Directorate for Highways showed that traffic forecasts were considered to be sufficient to make the project feasible as the existing two bridges worked with overcapacity and the surplus capacity in these bridges could be directed to the new bridge (Sabah [13]). However, opponents still claimed that the new bridge was far away from settlements and thus questioned the attractiveness of the new bridge for citizens. In this respect even the State Planning Organization advocated that traffic forecasts were over-optimistic. Although the canalization of the heavy vehicles to the third bridge was considered, the decision was not statutory. 
Consequently, several important modifications were made in the minimum traffic guarantees provided by the public sector. In the first tender, the government had agreed to support the project by a minimum traffic guarantee of 100,000 vehicles, whereas the volume was increased to 135,000 vehicles in the second tender. However, unlike other toll road project examples from the world, no ceiling level of traffic demand has been determined.

The assumption of revenue risks by the public sector was one of the most important moves to make the project feasible for investors. The reason for this is the importance attached to traffic demand or revenue risks in the success of BOT-type toll road projects. Previous experience shows that there is a close relationship between shortness of demand and project failures. For example, many BOT projects in Mexico, Hungary and Thailand have failed due to unrealistic assumptions about future traffic demands and the inappropriate revenue risk allocation between the public sector and the private sector (Ashuri et al. [14]). The level of predictability of future traffic demand is the main determinant for setting an appropriate revenue risk allocation structure between the public and the private sector. A project company can generate revenues from a toll road either in the form of direct toll payments from end users or through indirect payments by the contracting authority based on usage. High predictability of traffic level increases the attractiveness of projects for financiers as it will be easier to identify whether toll revenues that will be generated from the project will be sufficient to cover debt service. While the market demand can easily be predicted for improvements to existing roads, traffic forecast become more uncertain in new roads such as the Northern Marmara Motorway Project. Generally, the usage risk is transferred to the private sector in case the expected traffic levels can easily be predicted. In the latter case, however, usually the public sector retains market demand risks through minimum traffic or revenue guarantees.

Increasing minimum traffic guarantees were not the only public sector support that had a positive impact on revenues of the Northern Marmara Project. Another important move to make the project feasible for investors was the announcement of a law about exemption from VAT for BOT projects. New regulation on VAT arrangements allowed a further $18 \%$ advantage in the costs of investors and increased the attractiveness of the project.

\subsection{Expropriation}

Another notable difference between the two tenders regards the level of expropriation risks assumed by the private sector. When the call for the first tender was announced, the date was postponed several times mainly due to demands from prospective bidders. In this respect, one of the concerns raised was about the high amount of expropriation costs that would be assumed by the private sector [approximately 950 million Turkish Lira (TL) over a total of 1.6 billion TL]. As a result, the expropriation costs that will be assumed by private investors were gradually reduced from 950 million TL to 700 million TL and finally to 400 million TL $(1 \mathrm{TL}=1.81$ \$ in 2012). Despite new demands from investors to further suspend the date, the General Directorate for Highways announced that the bidding date for the first tender could not further be postponed. However, the reduction in expropriation costs was not sufficient to increase private interest in the project and consequently no bids were submitted to the first tender, where 18 different groups of investors had purchased tender documents. As a result, the public authority agreed to assume all the costs associated with expropriation in the second tender. In this concept, the government stated that approximately $85 \%$ of the property in the route belonged to the public sector and thus the expropriation costs would not be very high (CNN Türk [7]). 


\subsection{Environmental impacts and social opposition}

In the beginning, the project was exempted from performing an Environmental Impact Assessment (EIA) report through a modification made in the EIA Ordinance. Undoubtedly, this further complicated the financing process as many financial institutions have strict policies on maximizing positive development impacts and thus do not provide finance for projects that have negative environmental or social impacts. However, it should also be noted that although the project was exempt from performing an EIA report, later the ministry have announced that an EIA report had been prepared as this is a prerequisite in the provision of funds in particular for foreign financial institutions.

The most striking social oppositions to the Northern Marmara Motorway were shown to the route of the project. An important issue regarding project scope is the altering of the route after the tendering process due to the cancellation of the master plan. In July 2013, many national newspapers reported the cancellation of 1/5,000 master and 1/1,000 implementary development plans (KGM [15]). Several reasons were put forward for this change. First, opponents claimed that the location and the route selected for the project were incorrect as they passed through Belgrade and Fatih Forests. Others claimed that the change in the route was required due to the manifestation of high expropriation costs in the previous route. As a response, ministry authorities decided to continue the route to more northern regions in order to minimize harm to forests. Another alteration was also made on the Asian side of the motorway route in an attempt to protect Polonezkoy National Park (Dünya [16]). However, despite the modifications, opponents further asserted that 'induced demand' would be created by the construction of new highways. Arguments centred on the vicious cycle that the construction of new highways would generate new traffic and hence create more demand for yet more roads. The environmental concerns were soon brought to trial. However, the lawsuits against the project opened by professional chambers and non-governmental organizations were not concluded at the time of tender. Therefore, it can be observed that the project was extremely risky for financial institutions that did not want to take the risk of cancellation.

The alterations made to the project signal weakness in the feasibility phase of the project. The feasibility phase of these kinds of mega projects is extremely important. Detailed studies on alternative routes should involve a closer examination and comparative analysis of expropriation costs. The results from this analysis should then be combined with economic, social and environmental impact reports in order to take a decision.

\subsection{Other forms of public guarantees}

Finally, it is also important to mention that several other forms of credit guarantees are provided by the Turkish government after the project has been awarded to the ICA JV. One of the significant attempts was the provision of treasury guarantees for the project in 2014. According to the new legislation, only the debt provided by international banks will be assumed by $85 \%$ of the outstanding debt in case of an early termination of the contract as a consequence of project company default. In other forms of termination such as voluntary termination and force majeure events, the debt assumption commitment covers $100 \%$ of outstanding debt.

\section{CONCLUSION}

This study intensively tried to focus on the application of the BOT toll road model in practice. Although the findings cannot be generalized, the lessons learned offer relevant insights for both private and public sector providers of transportation projects in Turkey and in other developing countries. 
Several conclusions can be drawn from the way in which the challenges are dealt with in the realization of the third bridge and Northern Marmara Motorway Project. First, political support in each stage is extremely important. Without the project-specific support provided by the government, the case study project would not be accomplished due to financial problems. Second, a clear risk assumption structure by the appropriate partner is imperative for economic viability. Revenue risks in BOT toll road projects are of particular importance. In this regard, the predictability of future traffic volume should be the main determinant of risk allocation between private and public sectors. Third, strong political support and the assumption of revenue risks by the public sector may not be sufficient to increase the attractiveness of projects for financial institutions. The case study has shown that despite the strong government support, negative public perception and in particular environmental concerns complicate the financing process. Treasury credit guarantees provided after the tender prove that environmental problems and social oppositions which lead to lawsuits are perceived to be a very important risk factor for financial institutions. The case study once again has demonstrated the strength of interactions between financial and environmental viabilities of projects. Therefore, above all, a comprehensive and integrated assessment of environmental, technical and economic aspects in the feasibility phase and a clear legal structure to base these evaluations are crucial for success not only in BOT toll road projects.

Consequently, these findings address to structural problems independent from the scope of the case study. Developing countries' lack of political and economic stability, proper regulations and environmental policy are a candidate to encounter identical issues in various kinds of BOT projects (e.g. airports, toll roads, bridges, power plants, etc.). Temporary and political endeavours to solve problems faced off in the context of single project do not work well in long-term outcomes.

\section{REFERENCES}

[1] Gundes, S. \& Ergonul, S., The management of large-scale projects: the case of Marmaray. Proceedings of the Infrastructure Middle East 2011, p. 108, 2011.

[2] Proverbs, D. \& Gameson, R., Case study research. Advanced Research Methods in Built Environment, eds. A. Knight \& L. Ruddock, Wiley-Blackwell: Chichester, pp. 99-110, 2008.

[3] Fellows, R. \& Liu, A., Research Methods for Construction, Wiley-Blackwell: Chichester, pp. 93-94, 2015.

[4] Karayolları Genel Müdürlügüu (KGM). [image], 2010, available at http://www.kgm.gov. tr/Sayfalar/KGM/SiteTr/KgmAbCalismalari/TurkiyeTEN-TKarayoluGuzergahlari. aspx (accessed 14 April 2015).

[5] Anadolu Ajans1, 3. Köprü İhalesi Ertelendi, 2012, available at http://www.aa.com.tr/tr/ ekonomi/42934--3-kopru-ihalesi-ertelendi (accessed 30 January 2015).

[6] Anadolu Ajans1, 36 Ayda Tamamlanacak, 2012, available at http://aa.com.tr/tr/ ekonomi/3-koprude-teklifler-aciliyor/365260 (accessed 2 February 2015).

[7] CNN Türk, 3. Köprü İhalesini İçtaş-Astaldi Yapacak, 2012, available at http:// www.cnnturk.com/2012/ekonomi/genel/05/29/3.kopru.ihalesini.ictas.astaldi. yapacak/662853.0/ (accessed 6 February 2014).

[8] Construction Week, Hyundai Consortium Wins \$697m Turkey Bridge Deal, 2013, available at http://www.constructionweekonline.com/article-23321-hyundai-consortiumwins-697m-turkey-bridge-deal/ (accessed 8 February 2014). 
[9] Fishbein, G. \& Barbar, S., Private Financing of Toll Roads, RMC Discussion Paper Series 117, The World Bank: Washington, DC, pp. 14-20, 1996.

[10] Habertürk, İşte 3. Köprü için Yeni İhale Bedeli, 2012, available at http://www.haberturk.com/ekonomi/makro-ekonomi/haber/709677-iste-3-kopru-icin-yeni-ihale-bedeli (accessed 9 February 2014).

[11] Hürriyet, KDV'den Muaf Tutuldu Araç Garantisi 135 bine Yükseldi, 2012, available at http://www.hurriyet.com.tr/ekonomi/20389990.asp (accessed 14 February 2014).

[12] Reuters, Funding Crunch Sinks Turkey Mega-Highway Tender, 2012, available at http:// fr.reuters.com/article/idUKL6E8CA1DP20120110?pageNumber=1\&virtualBrand Channel=0 (accessed 11 January 2014).

[13] Sabah, Kapasite 250 bin Geçen Araç 550 bin, 2010, available at http://www.sabah.com. tr/yasam/2010/10/09/kapasite_250_bin_gecen_arac_550_bin (accessed 3 March 2014).

[14] Ashuri, B., Kashani, H., Molenaar, K., Lee, S. \& Lu, J., Risk-neutral pricing approach for evaluating BOT highway projects with government minimum revenue guarantee options. Journal of Construction Engineering and Management, 138(4), pp. 545-557, 2012. DOI: 10.1061/(ASCE)CO.1943-7862.0000447.

[15] KGM, Kuzey Marmara İmar Planları Hk, Official Letter, No. 48030629-754/12545. Ankara, 2012.

[16] Dünya, İşte 3. Köprü'nün Değişen Planı, 2013, available at http://www.dunya.com/iste3-koprunun-degisen-plani-198071h.htm (accessed 11 January 2014). 